Tropical Agricultural Pesearch \& Extension 22 (3 \& 4): 2019

\title{
POST-HARVEST LOSS EFFECTS ON INCOME INEQUALITY ALONG THE ORANGE SUPPLY CHAIN IN OYO STATE, NIGERIA
}

\author{
Obayelu OA*, Dairo D and Ojo A \\ Department of Agricultural Economics, University of Ibadan, Nigeria
}

\begin{abstract}
One third of citrus fruits produced in Nigeria is wasted due to post-harvest losses with an attendant increased demand-supply gap of citrus. A reduction in post-harvest loss of orange will not only affect the income of both farmers and marketers but also reduce the income inequality in its supply chain. This study investigated the postharvest loss effects on income inequality along the orange supply chain. Specifically, a multistage sampling technique was used to select sixty orange farmers, from Oyo and Ogbomoso Agricultural Development zones and 40 wholesalers and 80 retailers from four major fruit markets. Data were analysed using descriptive statistics, gross margin analysis, Gini coefficient and Lorenz curve. Retailers had the lowest revenue \$15.47/month) from orange, while producers had the highest revenue (\$318.44/month). Specifically, income inequality was higher among wholesalers $(0.82)$ than among producers $(0.05)$ and retailers $(0.56)$. Inequality was highest among wholesalers with 6-10 percent post-harvest losses $(0.8180)$ but lowest among farmers with post-harvest losses of $\leq 5$ percent.
\end{abstract}

Keywords: Gross margin, Inequality, Nigeria, Orange marketers, Post-harvest loss

\section{INTRODUCTION}

Fruits production and marketing are veritable sources of income for rural and urban dwellers in Nigeria (Dimelu and Odo 2013;). Generally, fruits and vegetables constitute a group of horticultural crops. Horticultural crop production creates more jobs per hectare of production compared to cereal crop production based on the labour requirements (Ali and Porciuncula 2001). Over the past decade, the global demand for orange has grown rapidly with a global increase in imports of orange from 5 758,400 tonnes in 2008 to an estimated 7 011,600 tonnes in 2016 (FAO 2017). However, the proportion of total harvest that finally gets to the final consumer is reflective of the level of agricultural development in developing countries (Idah et al. 2007). An estimated $30 \%$ of Nigeria's agricultural products cannot be accessed due to post-harvest losses (Atanda et al. 2011). Again, about 30\% of citrus fruit produced is wasted due to post-harvest losses while $45 \%$ are consumed fresh and $25 \%$ are processed (NIHORT 2000).

*Corresponding author: jkemmyade@yahoo.co.uk
Post-harvest losses in tropical fruits vary widely from 10 percent to 80 percent in both developed and developing countries (FAO 2006; Kitinoja et al. 2018). The losses occur across the supply chain from the point of harvesting, packing, storage, transportation, retailing to consumption (WFLO 2010). In most developing countries, a combination of poor infrastructures and logistics, poor farm practices, lack of post-harvest handling knowledge and a convoluted marketing system has been linked to high post-harvest losses (FAO 2006;). Kitinoja (2002), Ray and Ravi (2005) and WFLO (2010) observed that between $40 \%$ and $50 \%$ of horticultural crops including fruits and vegetables are lost before they reach consumers. The main reason for the loss is due to high rates of bruising, water loss and subsequent decay during post-harvest handling (Kaminski and Christiaensen 2014;). Further, the quality of fresh produce is affected by post-harvest handling and storage conditions (Sablani et al. 2006). Losses occur along the supply chain as a result of limited resources such as post-harvest technology 
infrastructure and knowledge gaps (Parfitt et al. 2010). Post-harvest losses of orange can therefore be attributed to poor post-harvest management at peak production periods. Oranges are perishable and therefore tend to mature almost at once causing seasonal gluts coupled with inadequate storage facilities resulting in post-harvest management challenges when in season (Tschirley et al. 2011). Previous studies had focused on rice, maize and vegetable value chains (Muhammad et al. 2012; Oguntade et al. 2014 ) while a few analysed post-harvest losses in the citrus value chain (Busari et al. 2015; Olife et al. 2015). However, post-harvest losses and the ripple effect on income and income inequality among players in the Nigerian orange supply chain has not received sufficient attention in the literature. Hence, this study attempts to fill this identified gap.

All the aforementioned problems reduce the life span of fruits and consequently reduced the quality and quantity of fruits that get to the market, thereby forcing farmers and marketers to sell fruits at low prices. Post-harvest losses lower the gains of the farmers causing inequality in the supply chain (Babalola et al. 2010). Since the production and marketing of oranges are sources of income for rural and urban dwellers any reduction due to post-harvest loss will not only affect the income of both farmers and marketers but also the income inequality among them. This implies that a significant reduction in post-harvest losses is thus one of the ways of improving the income and reducing income inequality. Income inequality has been defined as a measure of the distribution of income across. It is a relative comparison of the gap in income within and between groups (Deininger and Squire 1996). This study therefore, analyzed the effect of post-harvest losses on income inequality among orange supply actors in Oyo State .

\section{MATERIALS AND METHODS}

A multi-stage sampling technique was used to select the sample from the orange farmers for the study in 2018. Four Local Government Areas (Afijo, Ona Ara, Ogooluwa and Egbeda) of Oyo State were purposively selected based on the predominance of orange production and marketing. A simple random sampling technique was used to select 15 farmers from each of the local governments i.e. a total of 60 farmers were sampled. The orange farmers either had their farms in homestead, boundary, or orchard forms (Oyedele and Yahaya 2010). Similarly, a two-stage sampling technique was used to select orange wholesalers and retailers for the study. A major fruit market was purposively selected in each of the four production areas, where oranges from the farmers are sold in commercial quantities (Elekara, Oje, Odo-Oba and Egbeda) in Oyo state. A simple random sampling was used to select 10 orange wholesalers from each of these markets, making a total of 40 wholesalers. A simple random sampling was also used to select 20 orange retailers who came to buy oranges from each of the markets, totaling 80 retailers.

\section{Analytical techniques}

Descriptive statistical tools were used to profile the actors while the Gini coefficient was used to assess the income inequality among the actors. Following FAO (2018), PHL was estimated using following equations.

$$
\begin{aligned}
& \mathrm{PHL}_{\text {producer }}=\frac{\text { Quantity produced - Quantity sold }}{\text { Quantity produced }} \\
& \mathrm{PHL}_{\text {wholesaler/retailer }}=\frac{\text { Quantity bought - Quantity sold }}{\text { Quantity bought }}
\end{aligned}
$$

Income from orange was the gross margin from sales and was estimated as the difference between the total revenue and total variable costs incurred.

$$
\begin{aligned}
\text { Gross Margin }_{\frac{\text { producer }}{\text { marketers }}} & = \\
\text { Total Revenue } & - \text { Total Variable Cost }
\end{aligned}
$$

Gini coefficient is a numerical representation of the degree of income inequality in the population. The Gini coefficient ranges between 0 and 1 used in determining the level of concen- 
tration in the market structure. A Gini coefficient of 0 is indicative of perfect equality in concentration while a coefficient of 1 means perfect inequality, the higher the concentration, the higher the level of income inequality in the supply chain (Morduch and Sicular 2002). Mathematically expressed as:

$$
G C=1-\sum_{k=0}^{n}\left[\left(X_{k}-X_{k-1}\right)\left(Y_{k}+Y_{k-1}\right)\right]
$$

Where GC=Gini coefficient; $\mathrm{X}_{\mathrm{k}}$ is the cumulated proportion of the population variable, for $\mathrm{k}=0 \ldots \mathrm{n}$, with $\mathrm{X}_{0}=0$ and $\mathrm{X}_{\mathrm{n}}=1$; and $\mathrm{Y}_{\mathrm{k}}=$ the cumulated proportion of the income variable, for $\mathrm{k}=0 \ldots . . \mathrm{n}$, with $\mathrm{Y}_{0}=0$ and $\mathrm{Y}_{\mathrm{n}}=1$

\section{RESULTS AND DISCUSSION Socioeconomic profile of respondents}

Results showed that the surveyed producers, wholesalers and retailers were within the economically active period of their lives and can improve on the current level at which they operate (Table 1). However, the producers were the oldest $(52 \pm 10.72$ yearrs $)$ while the retailers were the youngest ( $44 \pm 12.20$ years). This corroborates the earlier findings of Busari et al. (2015) that a majority of fruit marketers in Lagos metropolis were between the ages of 30 and 49 years. Similarly, a typical producer had seven household members while wholesalers and retailers had six and five household members, respectively. Large farming household size is typical of farming households as they provide family labour for productions of oranges. The respondents were experienced in their chosen economic activities with producers having an average of 24 years of experience, while wholesalers and retailers had 19 and 20 years, respectively. The farm size cultivated by the producers was low (2ha on average), which is characteristic of the smallholder farmers who constitute the majority of the Nigerian agricultural production landscape (Anderson et al. 2017). All the categories of respondents (producers, wholesalers and retailers) barely had post-secondary education. Furthermore, the mean percentage post-harvest loss was highest among wholesalers at $10 \%$ compared to $9 \%$ and $4 \%$ among farmers and retailers respectively. This can be linked to the high volume that the wholesaler has to transport and the risk of accidents and spoilage, which is consistent with the findings of James et al. (2017)

\section{Gross margin for orange supply chain}

The gross margin after the post-harvest loss was highest for the producer $(\$ 287.40)$ but least for retailers $(\$ 14.71)$. Wholesalers accrued the highest variable cost $(\$ 158.23)$, while the retailers had the least $(\$ 0.76)$. The retailers had the lowest gross margin, revenue

Table 1: Mean of continuous variables of producers, wholesalers and retailers $(\mathrm{N}=180)$

\begin{tabular}{|c|c|c|c|}
\hline Variables & Producers & Wholesalers & Retailers \\
\hline \multicolumn{4}{|l|}{ Producers } \\
\hline Age (years) & $52.16(10.72)$ & $45.69(12.28)$ & $43.60(12.20)$ \\
\hline Household size & $7.11(2.15)$ & $6.00(2.73)$ & $5.19(0.66)$ \\
\hline $\begin{array}{l}\text { Farming/Marketing experience } \\
\text { (years) }\end{array}$ & $23.91(11.37)$ & $19.46(6.71)$ & $20.16(10.49)$ \\
\hline Farm size (Hectares) & $2.26(2.18)$ & - & - \\
\hline $\begin{array}{l}\text { Distance from farm to market } \\
(\mathrm{km})\end{array}$ & $2.99(3.15)$ & - & - \\
\hline Years of education (years) & $12.42(5.54)$ & $11.54(5.07)$ & $13.48(4.33)$ \\
\hline Per capita income (Naira) & $6658.87(4120.14)$ & $2546.82(5218.22)$ & $21203.89(92092.16)$ \\
\hline Post-harvest loss (\%) & $8.65(2.81)$ & $9.69(2.31)$ & $4.22(0.94)$ \\
\hline
\end{tabular}

Figures in parenthesis are standard deviation 
Table 2: Average gross margin per month for the actors in the orange supply chain

\begin{tabular}{llll}
\hline Variables & Producers & Wholesalers & Retailers \\
\hline Total Variable costs $(\$)$ & 31.04 & 158.23 & 0.76 \\
Total Revenue $(\$)$ & 318.44 & 263.78 & 15.47 \\
Gross Margin $(\$)$ & 287.40 & 105.55 & 14.71 \\
\hline
\end{tabular}

Income inequality along the supply chain

Wholesalers had the highest income inequality of 0.82 compared to 0.56 and 0.23 among producers and retailers, respectively (Table 3). Differences in the income distribution of wholesalers and producers can be linked to the high post-harvest losses obtainable within these groups. Again, an innovative postharvest losses reduction strategy can account for differences in economic outcomes of the different agents due to consequent cost reduction. Meanwhile, the reduced cost may result in lower prices and higher demand due to the signaling functions of price. Therefore, it is
Table 3: Gini Coefficient Results for income inequality

\begin{tabular}{lllll}
\hline & Farmers & $\begin{array}{l}\text { Whole- } \\
\text { salers }\end{array}$ & Retailers \\
\hline Quartile & $\begin{array}{l}\% \text { Total } \\
\text { income }\end{array}$ & $\begin{array}{l}\% \text { Total } \\
\text { income }\end{array}$ & $\begin{array}{l}\text { \% Total } \\
\text { income }\end{array}$ \\
\hline First & 0.0495 & 0.0515 & 0.1354 \\
Second & 0.1287 & 0.1031 & 0.1829 \\
Third & 0.3501 & 0.1649 & 0.2708 \\
Fourth & 0.4717 & 0.6804 & 0.4109 \\
Gini & 0.0495 & 0.8207 & 0.5617 \\
\hline
\end{tabular}

Table 4: Gini decomposition of farmers' income by demographic characteristics

\begin{tabular}{|c|c|c|c|c|c|c|}
\hline Group & $\begin{array}{l}\text { Gini } \\
\text { index }\end{array}$ & $\begin{array}{l}\text { Absolute } \\
\text { contribution }\end{array}$ & $\begin{array}{l}\text { Relative } \\
\text { contribution }\end{array}$ & Between & Within & Overlap \\
\hline Gender & & & & 0.0687 & 0.4587 & 0.140 \\
\hline Male & 0.1435 & 0.0687 & 0.4587 & & & \\
\hline Female & 0.1587 & 0.0151 & 0.1007 & & & \\
\hline Age & & & & 0.0586 & 0.0172 & 0.0739 \\
\hline$\leq 30$ & 0 & 0 & 0 & & & \\
\hline $31-40$ & 0.1628 & 0.0023 & 0.0157 & & & \\
\hline $41-50$ & 0.1158 & 0.0184 & 0.1226 & & & \\
\hline$>50$ & 0.1633 & 0.0379 & 0.2532 & & & \\
\hline Household size & & & & 0.0932 & 0.0251 & 0.0315 \\
\hline$\leq 5$ & 0.1464 & 0.0054 & 0.0359 & & & \\
\hline $6-10$ & 0.1460 & 0.0878 & 0.5865 & & & \\
\hline$>10$ & 0 & 0 & 0 & & & \\
\hline Educational level & & & & 0.0460 & 0.1422 & 0.0385 \\
\hline None & 0.1716 & 0.0216 & 0.1445 & & & \\
\hline Primary & 0.1530 & 0.0086 & 0.0578 & & & \\
\hline Secondary & 0.1270 & 0.0157 & 0.1048 & & & \\
\hline Tertiary & 0.0114 & 0 & 0.0001 & & & \\
\hline Farming Experience & & & & 0.0545 & 0.0164 & 0.0788 \\
\hline$\leq 5$ & 0.1612 & 0.0018 & 0.0120 & & & \\
\hline $6-10$ & 0.1141 & 0.0050 & 0.0333 & & & \\
\hline $11-15$ & 0.0858 & 0.0013 & 0.0086 & & & \\
\hline $16-20$ & 0.1645 & 0.0464 & 0.3100 & & & \\
\hline$>20$ & 0 & 0 & 0 & & & \\
\hline
\end{tabular}


likely that innovative economic agents will control the largest percentage of the market share.

\section{Gini Decomposition of Income/Gross mar- gin}

Income inequality was higher among female farmers (0.1587), farmers above 50 years of age $(0.1633)$ and farmers with household size less than and equal to $5(0.1464)$ (Table 4). Farmers with no education level (0.1716), farmers with years of experience 16- 20 $(0.1645)$ and farmers with post-harvest loss that falls between $6-10 \%(0.1741)$ also had higher income inequality. This can be linked to the gender considerations in the allocation of productive inputs in Nigeria and low per capita income associated with large households (Omonona and Okunmadewa, 2009; Awotide et al. 2012).
Income inequality was higher among female wholesalers (0.8889), wholesalers between the age 31 to 40 years $(0.8352)$ and wholesalers with a household size of 5 and below (0.7644) (Table 5). Wholesalers with tertiary education $(0.8325)$ and $16-20$ years of trading experience also had higher income inequality. The high-income inequality can be attributed to the challenges women face in accessing productive inputs and markets which affects their income (Palacios-Lopez and Lopez 2014).

Income inequality was higher among male retailers $(0.551)$, retailers below 30 years of age $(0.6189)$ and retailers with a household size less than and equal to 5 (0.6739) (Table $6)$. Retailers with primary education $(0.7034)$ and 11 to 15 years of orange retailing experience 11 - 15 (0.6638) had higher income ine-

Table 5: Gini decomposition of wholesalers' income by demographic characteristics

\begin{tabular}{|c|c|c|c|c|c|c|}
\hline Group & $\begin{array}{l}\text { Gini } \\
\text { index }\end{array}$ & $\begin{array}{l}\text { Absolute } \\
\text { contribution }\end{array}$ & $\begin{array}{l}\text { Relative } \\
\text { contribution }\end{array}$ & Between & Within & Overlap \\
\hline \multicolumn{7}{|l|}{ Wholesalers } \\
\hline Gender & & & & 0.2684 & 0.4860 & 0.0695 \\
\hline Male & 0.7122 & 0.2158 & 0.2618 & & & \\
\hline Female & 0.8889 & 0.0527 & 0.0639 & & & \\
\hline Age & & & & 0.2597 & 0.2529 & 0.3114 \\
\hline$\leq 30$ & 0.6667 & 0.0026 & 0.0032 & & & \\
\hline $31-40$ & 0.8352 & 0.1001 & 0.1215 & & & \\
\hline $41-50$ & 0.7500 & 0.0079 & 0.0096 & & & \\
\hline$>50$ & 0.7146 & 0.1491 & 0.1809 & & & \\
\hline Educational level & & & & 0.2345 & 0.2998 & 0.2898 \\
\hline None & 0 & 0 & 0 & & & \\
\hline Primary & 0.5238 & 0.0290 & 0.0352 & & & \\
\hline Secondary & 0.8325 & 0.0917 & 0.1113 & & & \\
\hline Tertiary & 0.7912 & 0.1138 & 0.1381 & & & \\
\hline Marketing Experience & & & & 0.1728 & 0.5827 & 0.0685 \\
\hline$\leq 5$ & 0 & 0 & 0 & & & \\
\hline $6-10$ & 0 & 0 & 0 & & & \\
\hline $11-15$ & 0 & 0 & 0 & & & \\
\hline $16-20$ & 0.8750 & 0.0295 & 0.0358 & & & \\
\hline$>20$ & 0.6476 & 0.1433 & 0.1739 & & & \\
\hline Household size & & & & 0.3646 & 0.3330 & 0.1264 \\
\hline$\leq 5$ & 0.7644 & 0.2803 & 0.3402 & & & \\
\hline$\overline{6}-10$ & 0.7619 & 0.0843 & 0.1023 & & & \\
\hline$>10$ & 0 & 0 & 0 & & & \\
\hline
\end{tabular}


Table 6: Gini decomposition of retailers' income by demographic characteristics

\begin{tabular}{|c|c|c|c|c|c|c|}
\hline Group & $\begin{array}{l}\text { Gini } \\
\text { index }\end{array}$ & $\begin{array}{l}\text { Absolute } \\
\text { contribution }\end{array}$ & $\begin{array}{l}\text { Relative } \\
\text { contribution }\end{array}$ & Between & Within & Overlap \\
\hline Gender & & & & 0.175 & 0.298 & 0.042 \\
\hline Male & 0.551 & 0.278 & 0.541 & & & \\
\hline Female & 0.266 & 0.019 & 0.038 & & & \\
\hline Age & & & & 0.0793 & 0.4728 & 0.0483 \\
\hline$\leq 30$ & 0.6189 & 0.0633 & 0.1055 & & & \\
\hline $31-40$ & 0.2078 & 0.0056 & 0.0093 & & & \\
\hline $41-50$ & 0.1382 & 0.0037 & 0.0062 & & & \\
\hline$>50$ & 0.1220 & 0.0067 & 0.0111 & & & \\
\hline Household size & & & & 0.2884 & 0.1190 & 0.1930 \\
\hline$\leq 5$ & 0.6739 & 0.1934 & 0.3221 & & & \\
\hline $6-10$ & 0.4546 & 0.0950 & 0.1583 & & & \\
\hline Educational level & & & & 0.2055 & 0.0777 & 0.3172 \\
\hline None & 0 & 0 & 0 & & & \\
\hline Primary & 0.7034 & 0.0244 & 0.0406 & & & \\
\hline Secondary & 0.5329 & 0.0992 & 0.1653 & & & \\
\hline Tertiary & 0.5680 & 0.0819 & 0.1363 & & & \\
\hline Marketing Experience & & & & 0.0656 & 0.4209 & 0.1138 \\
\hline$\leq 5$ & 0.3542 & 0.0050 & 0.0084 & & & \\
\hline $6-10$ & 0.5002 & 0.0207 & 0.0345 & & & \\
\hline $11-15$ & 0.6638 & 0.0273 & 0.0456 & & & \\
\hline$>20$ & 0.1094 & 0.0123 & 0.0204 & & & \\
\hline
\end{tabular}

quality. This implies that post-harvest losses affect retailers differently and as such some retailers are better positioned to mitigate the risk of post-harvest losses than others. The within-group inequality in years of marketing experience was higher than between-group.

The level of post-harvest losses could account for differences in economic outcomes among farmers. Inequality was highest among wholesalers with 6-10 percent post-harvest losses $(0.8180)$ but lowest among farmers with postharvest losses of $\leq 5$ percent (Table 7 ). This might be due to the fact that farmers do not keep oranges for long before sales to the wholesalers, who have to store for some time in their stalls. Similarly, between- postharvest losses group inequality was highest among wholesalers (0.4631) but lowest among the producers/farmers (0.0519). Conversely, within- post-harvest losses group ine- quality was highest among producers $(0.1973)$ but lowest among wholesalers (0.0722). Between inequality was higher than withingroup inequality for all the supply actors, suggesting that income is unequally distributed among orange supply actors in the study area. post-harvest losses peculiarities within the groups were less important than betweengroup constraints

Lorenz curve of income inequality along the supply chain

The Lorenz curve shows the level of income inequality among producers, wholesalers and retailers in Oyo State. All the curves fall below the line of equality $\left(45^{\circ}\right.$ line) (Tura and Gashaw, 2017). The graph shows that income inequality was highest among wholesalers and lowest among the producers (Figure 1), which is consistent with the findings of Solumbe et al., 2014). 
Table 7: Gini decomposition by post-harvest loss

\begin{tabular}{|c|c|c|c|c|c|c|}
\hline Group & $\begin{array}{l}\text { Gini } \\
\text { index }\end{array}$ & $\begin{array}{l}\text { Absolute } \\
\text { contribution }\end{array}$ & $\begin{array}{l}\text { Relative } \\
\text { contribution }\end{array}$ & Between & Within & Overlap \\
\hline \multicolumn{7}{|c|}{ FARMERS } \\
\hline \multicolumn{4}{|c|}{ Post-harvest loss (\%) } & 0.0519 & 0.1973 & -0.0995 \\
\hline$\leq 5$ & 0.0958 & 0.0421 & 0.2816 & & & \\
\hline $6-10$ & 0.1741 & 0.0098 & 0.0654 & & & \\
\hline \multicolumn{7}{|c|}{ WHOLESALERS } \\
\hline \multicolumn{4}{|c|}{ Post-harvest loss (\%) } & 0.4631 & 0.0722 & 0.2887 \\
\hline$\leq 5$ & 0 & 0 & 0 & & & \\
\hline $6-10$ & 0.8180 & 0.3883 & 0.4712 & & & \\
\hline $11-15$ & 0.7889 & 0.0748 & 0.0908 & & & \\
\hline \multicolumn{7}{|c|}{ RETAILERS } \\
\hline \multicolumn{4}{|c|}{ Post-harvest loss (\%) } & 0.3352 & 0.0905 & 0.1747 \\
\hline$\leq 5$ & 0.6308 & 0.0475 & 0.0791 & & & \\
\hline$\overline{6}-10$ & 0.5543 & 0.2877 & 0.4793 & & & \\
\hline
\end{tabular}

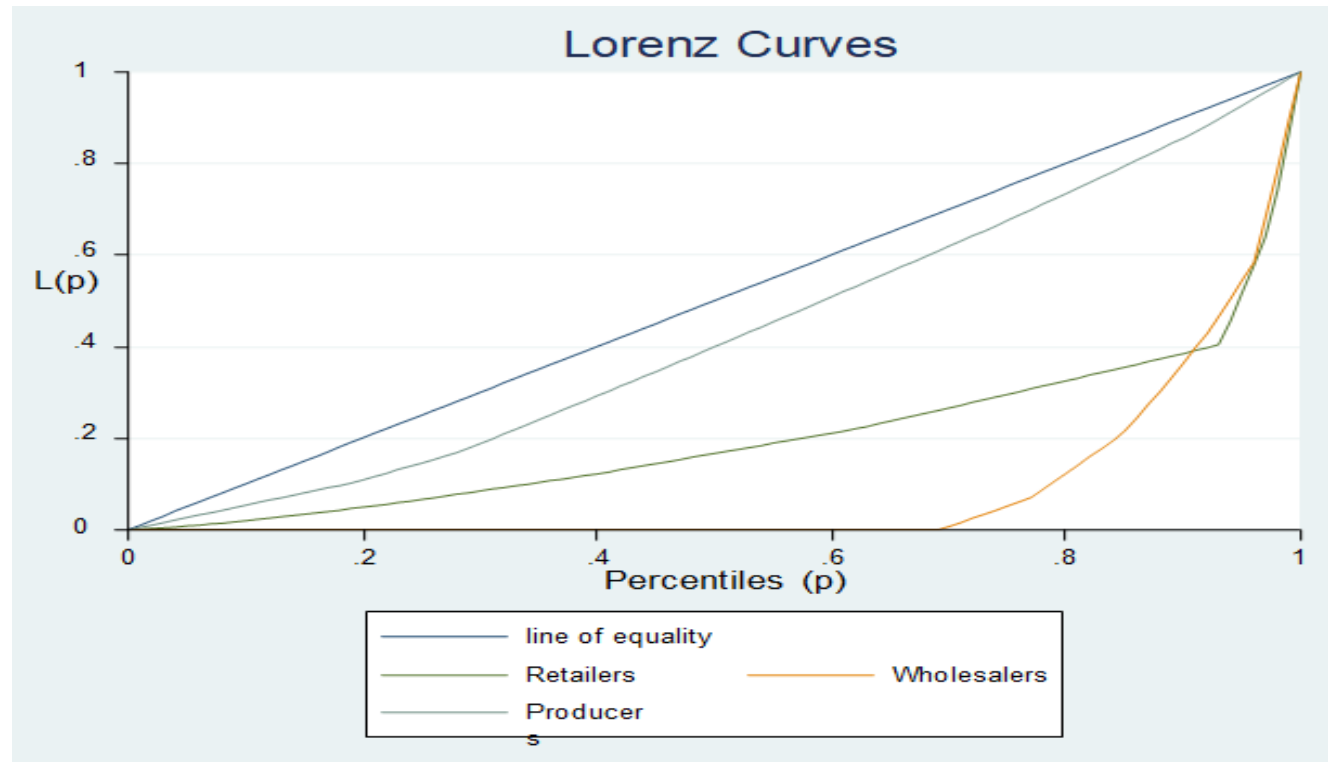

Figure 1: Lorenz curve showing the income inequality among producers, wholesalers and retailers in the population

\section{CONCLUSION}

This study found that post-harvest losses within the orange supply chain varied by category of the agent. Specifically, gross margin analysis revealed that wholesalers had the highest total variable cost, while the retailers had the lowest average cost. This might be linked to the level of post-harvest losses which drives production costs up thereby compromising the profitability of the wholesalers. Furthermore, post-harvest losses were about 10 percent among wholesalers compared to nine percent and four percent among producers and retailers respectively, implying that wholesalers and producers were more affected by post-harvest losses than retailers. The high cost of marketing and post-harvest loss might be a result of the high volume of oranges sold by the wholesalers. However, income inequality was also highest among wholesalers but least among the producers. To reduce income inequality, there is a need to 
focus on PHL constraints among of the supply actors especially concerning PHL skill acquisition in their respective enterprise. This should include appropriate training for all actors within the orange supply chain on postharvest reduction and management, especially among aging female farmers than among youthful, male wholesalers.

\section{REFERENCES}

Ali M and Porciuncula F 2001 Urban and peri -urban agricultural production in Metro Manila: resources and opportunities for vegetable production, AVRDCThe World Vegetable Center, Technical Bulletin No. 32, Shanhua, Taiwan, 1-78pp.

Anderson J, Manta C, Musiime D and Thiam M 2017 National survey and segmentation of smallholder households in Nigeria: Understanding the demand for financial, agricultural and digital solutions. CGAP Working Paper, 193pp.

Atanda SA, Pessu PO, Agoda S, Isong IU and Ikotun I 2011 The concepts and problems of post-harvest food losses in perishable crops. African Journal of Food Science, 8(11): 603-613.

Awotide BA, Awoyemi TT and Oluwatayo IB 2012 Gender analysis of income inequality and poverty among Rural Households in Nigeria: Evidence from Akinyele Local Government Area, Oyo State. New York Science Journal, 5(10): 13-19.

Babalola DA, Makinde YO, Omonona BT and Oyekanmi MO 2010 Determinants of post-harvest losses in tomato production: A case study of Imeko-Afon Local Government Area of Ogun state. Acta SATECH Journal of Life and Physical Sciences, 3(2): 14-18.

Busari AO, Idris-Adeniyi KM and Lawal AO 2015 Food security and post-harvest losses in Fruit Marketing in Lagos Metropolis. Discourse Journal of Agriculture and Food Sciences, 3(3): 52-58.
Deininger K and Squire L 1996 A new data set measuring income inequality. The World Bank Economic Review, 10(3): 565-591.

Dimelu MU and Odo RN 2013 Production Preference and Importance of Fruit Species in home garden among rural households in Igbo-Eze North Agricultural Zone of Enugu State. African Journal of Agricultural Science, 8 (46):5733-5744.

Food and Agriculture Organization 2006 Postharvest management of fruit and vegetables in the Asia-Pacific Region. APO, 2006, ISBN:92-833-7051.

Food and Agriculture Organization 2017 Citrus fruit fresh and processed statistical bulletin 2016. Food and Agriculture Organization of the United Nations, Rome.

Food and Agriculture Organisation 2018 Guidelines on the measurement of harvest and post-harvest losses, pp1-137.

Idah PA, Ajisegiri ESA, and Yisa MO 2007 Fruits and vegetable handling and transportation in Nigeria. Australian Journal of Technology, 10(3): 175183.

James D, Bamishayi OM, Shamsudeen J, Williams $\mathrm{O}$, Olukunde $\mathrm{T}$ and Zainab $\mathrm{M}$ 2017 Analysis of post-harvest losses in orange marketing: case study of Yanlemo Orange Market in Kano State. Journal of Agriculture and Earth Science, 3(4):1-17.

Kaminski J and Christiaensen L 2014 Postharvest loss in sub-Saharan Africa. What do farmers say? World Bank Policy Research Paper 6831:1-34.

Kitinoja L 2002 Making the link: extension of post-harvest technology, In Postharvest Technology of Horticultural Crops (3rd edition). Kader AA Technical editor. UC DANR Publication 3311, 481-509pp.

Kitinoja L, Torala VY and Brondy A 2018 Challenges and opportunities for improved post-harvest loss measure- 
ments in plant-based food crops. Journal of Post-harvest Technology, 6 (4):16-34.

Morduch J and Sicular T 2002 Rethinking inequality decomposition, with evidence from rural China. The Economic Journal, 112: 93- 106.

Muhammad RH, Hionu GC and Olayemi FF 2012 Assessment of the post-harvest knowledge of fruits and vegetable farmers in Garun Mallam L.G.A. of Kano, Nigeria. International Journal of Development and Sustainability, 1 (2): 510-515.

National Institute for Horticultural Research 200025 Years of research into horticultural crops development in Nigeria (1975-2000), (eds) Denton OA, Alasiri KO, Adejoro MA.

Oguntade AE, Thylman D and Deimling S 2014 Post-harvest losses of rice in Nigeria and their ecological footprint. A research paper prepared for GIZ, 1$52 \mathrm{pp}$.

Olife IC Ibeagha OA and Onwualu AP 2015 Citrus Fruits Value Chain Development in Nigeria. Journal of Biology, Agriculture and Healthcare, 5(4):3647.

Omonona BT and Okunmadewa FY 2009 Determinants of poverty among farming households in Kogi State of Nigeria. Journal of Income Distribution, 18 (2):16-34.

Oyedele OO and Yahaya MK 2010 Citrus farmers' production constraints and attitude to training on improved techniques of citrus production. Journal of Agriculture and Social Research, 10 (2): 69-76.

Palacios-Lopez A and Lopez R 2014 Gender differences in agricultural productivity: The role of market imperfections. Working Paper No. 164061 of University of Maryland, Department of Agricultural and Resource Economics, 1$74 \mathrm{pp}$.
Parfitt J, Barthel M and Macnaughton S 2010 Food waste within food supply chains: quantification and potential for change to 2050. Philosophical Transactions of the Royal Society B: Biological Sciences, 365(1554): 3065-3081.

Ray RC and Ravi V 2005 Post-harvest Spoilage of sweet potato in tropics and control measures. Critical Reviews in Food Science and Nutrition, 45:623644.

Tschirley D, Donovan C, Gomes F and Cairns J 2011 Características do Sector Doméstico e Regional Hortícola e Prioridades para a Sua Modernização. Apresentado no $1^{\circ}$ Forum de AgroNegocios em Moçambique 25 de Maio de 2011. Available at http:// www.aec.msu.edu/fs2/mozambique/ ForumAgroNegociosMSU_portFinalMay.pdf,

Tura EG and Gashaw BA 2017 Sources of Income Inequality among Farm Households in Ethiopia using Gini Coefficient Approach. American Based Journal, 6(8):14-24.

Sablani SS, Opara LU and Al-Balushi K 2006 Influence of bruising and storage temperature on vitamin $\mathrm{C}$ content of tomato. Journal of Food, Agriculture and Environment, 4(1):54-56.

Solumbe IM, Iheanacho AC and Kwaghe PV 2014 Determinants of efficiency and income distribution in Fish farming: A case study of Urban Maiduguri metropolis. Nigerian Journal of Fisheries and Aquaculture, 2(1):54-59.

World Food Logistics Organization 2010 Identification of Appropriate Postharvest Technologies for Improving Market Access and Incomes for Small Horticultural Farmers in Sub-Saharan Africa and South Asia. WFLO Grant Final Report to the Bill \& Melinda Gates Foundation, March 2010. 318 pp. 